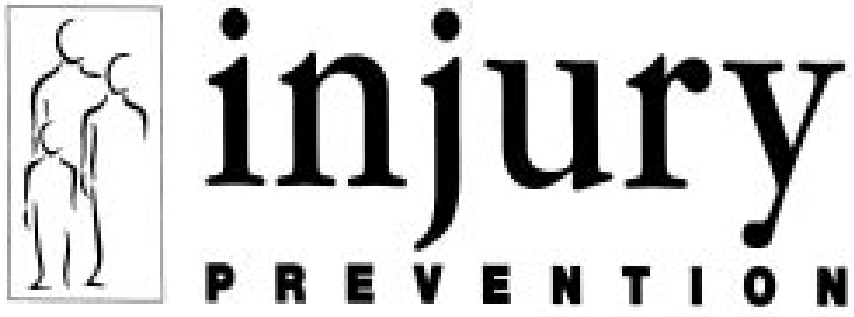

Journal of the International Society for Child and Adolescent Injury Prevention

\title{
Editorials
}

\section{Restraining children: a battle not yet won}

The "classic" in this issue is important for several reasons. First, it exemplifies the value of a deceptively simple and relatively inexpensive form of research: the observational study. Second, it illustrates how important such data can be in moving legislators to act. Third, it reminds us that insurance companies have an interest in the work of those involved in injury prevention, and should, therefore, be one of our strong supporters.

Finally, it should prompt us to take stock of our successes and failures in protecting children in cars. Once we do, it will be evident that, as the papers by Segui-Gomez et al and von Kries et al in this issue show, the battle is far from over. In the case of the former study, the method used is basically the same as that used by Williams nearly 30 years earlier.

The approach adopted by Williams seem simple, but as many have learned since this pioneering study of seat restraint use, they can be more complex than they appear. Observers need to be well trained so that two independent observers of the same event arrive at the same conclusions, not only about whether children are restrained, but also their approximate age, who else is in the car, etc. All this must be done quickly and accurately. The sites where observers are posted need to be carefully selected to avoid bias. And the conclusions drawn must be cautious, and, to be effective, well publicized. These difficulties should not intimidate other researchers. Even a relatively inexperienced community program, should be able to conduct a successful observational study with a little expert help.

As was the case with the Williams study, the data can and, where appropriate, should be used to prompt action. In this instance, it was by demonstrating the low rate of restraint use among children that politicians were eventually convinced that legislation was needed. The results persuaded them that common sense or education alone had not succeeded. For obvious reasons, most politicians would much prefer that a social good be accomplished by volun- tary rather than regulatory means, and, we agree. But when data such as these are presented, there seems little alternative. Parenthetically, it is interesting to recall that the first child restraint law in the US was prompted by the work of Sanders, a pediatrician. He, no doubt, used data of this kind to persuade the legislature to pass this law. Sanders never published an account of how he went about his task, but his example reminds us of what can be accomplished by determination and making good use of available data.

The third thought prompted by the juxtaposition of the classic and the paper by Segui-Gomez et al is a mixed one: on the one hand we should be reminded of how far we have advanced since the Williams study was done-from rates of restraint use in the 1970 s of about $20 \%$ to well over $80 \%$ in many areas today. Nevertheless, the battle is far from won. Not only are there countries where restraint use rates remain much, much lower-in part, no doubt, because they have failed to pass legislation - but even in areas with high use rates, studies continue to show that many preschoolers are improperly restrained. Furthermore, rates among older children are, generally, alarmingly low. And, far too many children are placed in much more dangerous, front seat. Finally, precisely how, if at all, the airbag controversy has affected all this remains to be seen.

The message is simple: much has improved since the elegant study by Williams. But much more remains to be done. To succeed, safety advocates need each other and they need allies. The Insurance Institute for Highway Safety (IIHS) is an exemplary organization that has done much to promote the interests of the industry by sponsoring research. Readers who do not yet receive IIHS reports are urged to request them. Not only do they sponsor high caliber research of the kind conducted by Williams, but they also present the results in a convincing manner. This helps ensure that the key messages are easily understood by those with the power to improve matters.

\section{Risk homeostasis: a win-win situation?}

The Opinion/Dissent columns in this issue deal with one of the most contentious ideas in the safety field. The notion of risk homeostasis crops up constantly-in letters to the editor, in scientific articles, and in political debates. Although Wilde has been careful to present his controversial ideas as "theory", others treat them as proved. It seemed wise for this issue to be aired fully and this prompted my invitation to Professor Wilde to explain risk homeostasis to our readers.
It did not seem reasonable, however, to do so without providing an opportunity for rebuttal by those who are convinced that there is little or no foundation for Wilde's beliefs. Thus, quite coincidentally, I invited Brian O'Neill and Allan Williams of the IIHS mentioned above, to prepare a Dissent.

In brief, Wilde argues that measures taken to diminish risk are offset by behaviours that increase risk. Thus, a balance is maintained such that we should not expect to see 
any reduction in injuries accruing to new safety measures. Wilde believes that the only way to succeed in light of his theory is to somehow persuade the public to lower their acceptable level of risk taking. This is akin to setting the thermostat in your home to a lower temperature.

Wilde's critics point to flaws in his reasoning and misinterpretations of the data used to support this theory. In fact, some believe the data actually point to the opposite conclusions: that safety measures have had, for the most part, the intended effects. They note that restrained drivers do not drive faster. Certainly in the case of restrained children, there is nothing to suggest that after taking such measures to protect a child, a parent is then more inclined to carelessness in other aspects of car safety. If anything, we suspect that the reverse is true.

But instincts are often misleading and what is needed is solid scientific evidence and dispassionate judges of that evidence. Wilde and Williams and O'Neill marshall some of the data we need to draw our own conclusions. This debate will not soon or easily be resolved. And it may be that in some strange way, both sides will be shown to be right: that for safety advocates, the debate can be turned into a win-win situation.
What may be needed is that we heed Wilde's bottom line: that the level of acceptable risk must be lowered. Although it is not clear how this can be accomplished, there may be little reason for rejecting the notion out of hand. The only dissenters may be those who suggest that children can only learn to avoid harm by being injured. This idea is even more contentious (and, in my view, more foolish). But it, too, may deserve further scrutiny. If we knew how to persuade parents or children to lower their risk taking thermostats, surely we should do so.

At the same time, however, it would be folly on the strength of Wilde's arguments to abandon attempts to introduce new safety measures or not to implement those we have shown to be effective. On the contrary, whether we accept the Dissenting view or not, the experience of every safety group and most researchers tells us that technology, legislation, regulations, and education have all worked successfully together in the past to enhance child safety. They should continue to do so possibly with a little from our friends in psychology. Are crackdowns what they are cracked up to be?

I B PLESS

Editor

\section{A research consultation program for ISCAIP}

Many of us have just returned from the 4th World Conference on Injury Prevention and Control in Amsterdam, with our batteries recharged and with new ideas to develop and implement. The conference was a success, with five days of meeting and interaction. However, concerns linger about the quality of some of the research presented. Many a good idea foundered on the rocks of poor study design, inadequate implementation, inexpert data analysis, and poor presentation. I would like to make a modest proposal to the Society: that the Society should establish a research consultation program.

Alfred North Whitehead once remarked that the tragedy of human existence is that the young have imagination but little experience while those with experience have little imagination. While it may not be wholly true that seasoned researchers should be put out to pasture, it is hard to beat the creative energy of someone young and new to the field. In Seattle, the geniuses of Microsoft who design innovative software are all young whippersnappers under the age of 30. Watson was barely out of graduate school when he joined with Crick to discover the structure of DNA. The ability to see things from a fresh perspective has a wonderful potential to contribute fresh new insight and ideas for long standing problems.

Separate from the issue of individuals being inexperienced in research is the problem of isolation. Many investigators and injury control practitioners in all parts of the world work virtually alone. They may be the only individuals in their university or agency interested in injury control, able to do research or implement a program. They may not have available and willing mentors with the expertise to help them. Indeed, in some countries such mentors may simply not be available. Having worked in centers with many other colleagues for a number of years, I have become strong believers in the "critical mass concept", a large enough group in which ideas can be tested, critiqued, and refined to become viable and important projects. Every Friday morning in Seattle, my colleagues and I gather as a
Center to discuss a new idea or project, critique the preliminary data analyses or project evaluation, or evaluate the results of a project. We have practice sessions for talks, review posters, and critique each other's manuscripts and grant proposals. The same is true for Montreal and London and no doubt elsewhere. It is very difficult to do great work alone, and I have the deepest admiration for those able to be successful doing so. For many mere mortals, however, it is extremely difficult to do cutting edge work this way.

My proposal is that ISCAIP become a "virtual seminar" for injury control members. Those with experience and who are interested could volunteer to serve with one or a few others as a resource for individuals, wherever they may be. This could be conducted in real time by conference call, in virtual time via the internet, or at a slower, but for many, more feasible pace, using mailings of materials and comments. A central coordinating committee could triage materials to volunteers with expertise in a particular area, whether it be behavior modification, health education, study design, statistical analysis or presentation of results. This could be done from the inception of a project, through its design and implementation, data analysis and interpretation, and presentation of results either as a talk, poster, or article. This would not be just for research, but would be as applicable to program design, implementation, and evaluation.

Best of all, such consultation would be offered in a true collegial spirit and be free to ISCAIP members. I believe that such a program would be of substantial help to individuals at all levels of training, from students to professors, from field workers to agency heads. Let us know of your interest in ISCAIP establishing such a program. The ultimate winners, we hope, would be the children and adolescents who were protected from injury because of the imagination of the young and the experience of the old working together.

FREDERICK P RIVARA Chair, ISCAIP

Harborview Injury Prevention and Research Center,

Box 359960, 325 Ninth Ave, Seattle, WA 98104, USA 